\title{
UTILIZATION OF WATER TREATMENT PLANTS SLUDGE ASH IN BRICK MAKING
}

\author{
A.A.Mageed ${ }^{(*)}$, SH.A.Rizk ${ }^{(*)}$, and M.H.Abu-Ali ${ }^{(*)}$ \\ * Prof's of mineral processing in Mining\& Metallurgy Eng. Dept., faculty \\ of Eng. , Assiut Univ., Assiut, Egypt. \\ ** Demonstrator in Mining\& Metallurgy Eng. Dept, faculty of Eng., \\ Assiut Univ., Assiut, Egypt
}

(Received October 14, 2010 Accepted November 11, 2010)

The present study investigates the possibility of using water treatment plant (WTP) sludge of New Assiut city (Assiut- Egypt) as partial substitute for shale in brick making. Due to the high content of organic matter in water sludge, incineration of the WTP sludge is necessary to remove of all organic compounds contained therein. For brick making, mixture of various proportions from $10 \%$ to $50 \%$ by weight of sludge ash added to shale are used as raw materials in hand molding brick making. The produced brick samples after drying process and firing at $1000^{\circ} \mathrm{C}$ for $6 \mathrm{hr}$ 's, received a series of tests including firing shrinkage, weight loss on ignition water, absorption, bulk density, compressive strength, slake durability and efflorescence test. Satisfactory results were achieved when the percentage of sludge ash was up to 30\% (by wt.) or less in the mixture. The specifications of the produced bricks match the Egyptian standard ES: 1756/1989 of fired clay building units for non load bearing walls. The test results indicate that, the sludge ash proportions are one of the most important key factors determining the brick quality. Reuse of sludge ash as a construction and building material converts the waste into useful products that can alleviate the disposal and environmental problems.

KEYWORDS: Water treatment plant sludge, Clay bricks, Waste recycling.

\section{INTRODUCTION}

Recycling the water treatment plant (WTP) sludge is usually an attempt to reduce its volume, make it harmless and stable, recover useful contents and facilitate its safe disposal without imposing burden to the environment [1,2]. The sludge dry mass contains mainly high concentration of aluminum or iron salts, with mixture of organic and inorganic materials and hydroxide precipitates [2]. The mineralogical composition of the sludge is particularly close to that of clay and shale. This fact encourages the use of WTP sludge to be a potential substitute for clay or shale in brick making [3,4]. The use of WTP sludge in various industrial and commercial manufacturing processes has been reported in Taiwan, UK, Germany, USA and other parts of the world [4]. Many successful cases of reusing WTP sludge in brick, artificial aggregates and cement making has been reported by many investigators [2-12]. They concluded that satisfactory results were achieved when the ratio of WTP sludge in the range $15 \%$ to 
$30 \%$ by weight of the sludge-clay mixture. The produced bricks have good properties matching the requirements of the standard specification in their countries.

Successful bench scale trials were carried out by some Egyptian investigators [4] to reuse the sludge of Giza WTP (in southern part of Cairo) in brick making. The pre-incinerated sludge was mixed with shale in various proportions as firing material for the brick making process using hydraulic piston. The ratio of the pre-incinerated sludge was from 50 to $80 \%$ by weight. The results indicated that $50 \%$ pre-incinerated sludge was the optimum ratio in the molded mixture to produce brick that satisfy the requirements of Egyptian standard specification ESS, 1524/1993 [13] for load bearing walls.

In Egypt, most of the WTP constructed on the Nile river banks, discharged the generated sludge directly into the Nile River without treatment, which causes certain environmental problems and health hazards [4]. The others which were constructed far from the Nile river banks dispose the sludge to the available space close to the water treatment plants. One of these plants is the WTP of the New Assiut city (Assiut, Egypt) which is far from the Nile river banks by $22 \mathrm{~km}$ in the Eastern desert [14]. Its daily production from potable water is about 26000 tons/day. This amount is expected to be increased to about 52000 tons/day, due to the increasing demand for potable water by consumers. The raw water is pumped from the Nile River through a pipe line extended in the Eastern desert $22 \mathrm{~km}$. the generated sludge mainly from washing the sedimentation tanks was collected and pumped outside the plant in a slurry form (containing 1 to $4 \%$ solids by weight) to a gravel pit close to the plant and left to dry naturally in air and sun till the next washing time of sedimentation tanks. The accumulation of the sludge constitutes environmental problem and must be removed.

The main objective of this research is to reuse the generated sludge from the New Assiut city plant in brick making to get a product, which has some economic value. Therefore, use of sludge as construction and building material converts the waste into useful products that can alleviate the disposal problems.

\section{EXPERIMENTAL WORK}

The study was divided into three phases, consisting of preparing and mixing the raw materials, the experiment of bench scale brick production using shale and WTP sludge as raw materials and ultimately, testing the properties of the produced product. Figure 1 shows a flowchart of the experimental procedures of brick making for the present study.

\section{Material}

WTP sludge and shale were the two main raw materials used in brick making tests. The WTP dried sludge sample was sludge obtained from the disposal area surrounding the WTP of New Assiut city. Shale sample for brick making was obtained from local area of Assiut quarries. Both samples were dried at $110^{\circ} \mathrm{C}$ for over 24 hours, cooled at room temperature, and crushed to a size smaller than $315 \mu \mathrm{m}$. The basic physicochemical characteristics of the two materials were analyzed. The X-ray fluorescents spectrometry (XRF) was used to identify the major components of WTP sludge and shale. The physical and chemical properties of the dried WTP sludge and shale are summarized in Tables $1 \& 2$. From Table 1 and Table 2, it is noticed that both 
samples are high in organic content and low in ash content. The high loss on weight of WTP sludge suggests that the pre-incineration of sludge is necessary before blending with shale.

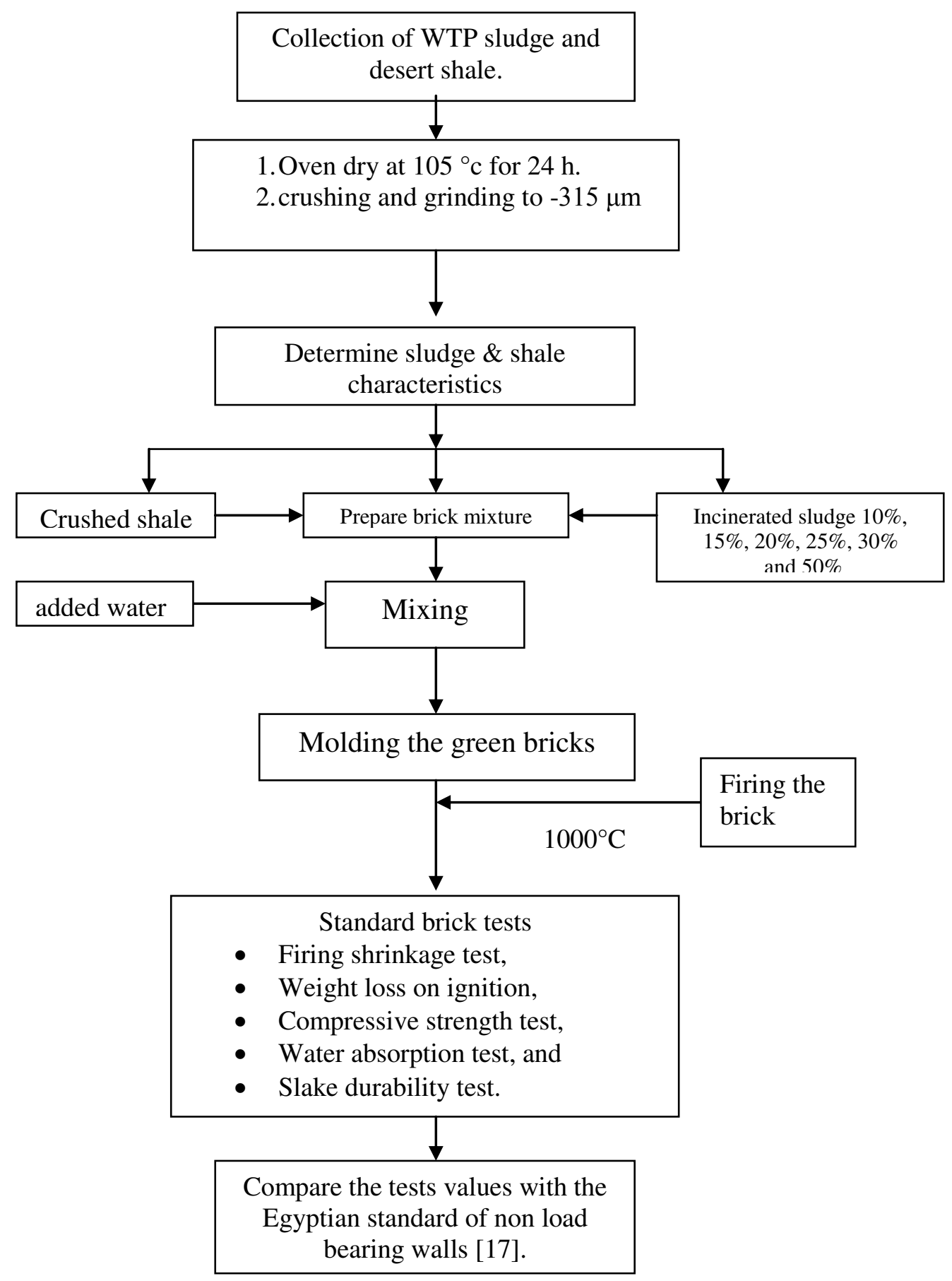

Figure 1: Flow chart describing brick- making methodologies. 
Table 1: Characteristics of water treatment sludge and shale

\begin{tabular}{|c|c|c|}
\hline Parameter & Dried sludge & Shale \\
\hline $\mathrm{pH}$ & 7.46 & 8.01 \\
Moisture content. & $14.33 \%$ & $1.60 \%$ \\
LOI* & $39.43 \%$ & $14.72 \%$ \\
Ash content & $60.57 \%$ & $85.28 \%$ \\
Volatile matter** & $34.74 \%$ & $8.26 \%$ \\
Density*** & $1.55 \mathrm{~g} / \mathrm{cm}^{3}$ & $2.61 \mathrm{~g} / \mathrm{cm}^{3}$ \\
Carbonates $\left(\mathrm{CaCO}_{3}\right)$ & $00 \%$ & $13.69 \%$ \\
\hline
\end{tabular}

* Fired at $850^{\circ} \mathrm{C}$ for $3 \mathrm{hr}$. *** Combusted at $550^{\circ} \mathrm{C}$ for $3 \mathrm{hr} \quad * * *$ True density

The major chemical composition of natural dried WTP sludge and shale are silicon, aluminum, and iron oxides as given in Table 2. As shown from table 2 the WTP sludge, on the other hand, has much higher Al content and lower $\mathrm{SiO}_{2}$ content than the shale. Since the strength of the brick depends largely on silica, the strength of the brick made from WTP sludge alone may be impaired and hence, pre-incineration of WTP sludge is necessary in brick making. The WTP sludge was incinerated in combustion chamber at $850^{\circ} \mathrm{C}$ to remove all organic substance. The incinerated sludge ash was then used as a shale substitute without further treatment.

Table 2 : Chemical compositions of dried sludge and shale

\begin{tabular}{|c|c|c|}
\hline \multirow{2}{*}{ Composition } & \multicolumn{2}{|c|}{$(\mathrm{w} / \mathrm{w}) \%$} \\
\cline { 2 - 3 } & Dried sludge & Shale \\
\hline $\mathrm{SiO}_{2}$ & 28.80 & 49.03 \\
$\mathrm{Al}_{2} \mathrm{O}_{3}$ & 20.30 & 12.60 \\
$\mathrm{Fe}_{2} \mathrm{O}_{3}$ & 2.62 & 7.45 \\
$\mathrm{~K}_{2} \mathrm{O}$ & 0.20 & 0.76 \\
$\mathrm{Na}_{2} \mathrm{O}$ & 0.74 & 1.23 \\
$\mathrm{CaO}$ & 1.94 & 8.28 \\
$\mathrm{MgO}$ & 1.26 & 2.82 \\
$\mathrm{P}_{2} \mathrm{O}_{5}$ & 0.12 & 0.16 \\
$\mathrm{SO}_{3}$ & 0.37 & 0.16 \\
$\mathrm{TiO}_{2}$ & 0.26 & 1.14 \\
$\mathrm{Cl}$ & 0.53 & 1.40 \\
L.O.I & 42.81 & 15.07 \\
\hline
\end{tabular}

\section{METHOD OF BRICK MAKING}

In the brick molding process, different WTP sludge ash proportions from 10 to $50 \%$ by weight were mixed with shale. The samples were mixed and blended with appropriate amount of water, and then molded manually into cubic wooden molds of $5 * 5 * 5 \mathrm{~cm}$ without press using hand smoothing method. Brick sample from shale only without addition of sludge ash was used as a reference specimen. The blend proportions of sludge ash and shale are given in Table 3. 


\section{Table 3: The blend proportions used in brick making}

\begin{tabular}{|c|c|c|c|c|}
\hline Group No. & Test No. & Shale, $\%$ & Sludge ash, $\%$ & Size of samples \\
\hline & 1 & 100 & 0 & \\
& 2 & 90 & 10 & Brick cubes of \\
& 3 & 85 & 15 & size $5 * 5 * 5 \mathrm{~cm}$. \\
I & 4 & 80 & 20 & \\
& 5 & 75 & 25 & \\
& 6 & 70 & 30 & \\
& 7 & 50 & 50 & \\
II & 8 & 100 & 00 & Half scale \\
& 9 & 80 & 20 & bricks of size \\
& 10 & 75 & 25 & $12.5 * 6 * 3 \mathrm{~cm}$. \\
\hline
\end{tabular}

The molded brick samples were first left to dry for two days and turned over to facilitate uniform drying. After two weeks of being dried in open air and sun, the green samples were fired in an electrical muffle furnace at $1000^{\circ} \mathrm{C}$ firing temperature for 6 hours duration time. The produced brick samples as shown in Figure 2 (a) received a series of tests including firing shrinkage, weight loss on ignition, water absorption, bulk density, slake durability test, compressive strength, and efflorescence test to determine a suitable condition for producing half scale bricks of dimension $12.5 * 6 * 3$ cm. (Fig. 2-b).

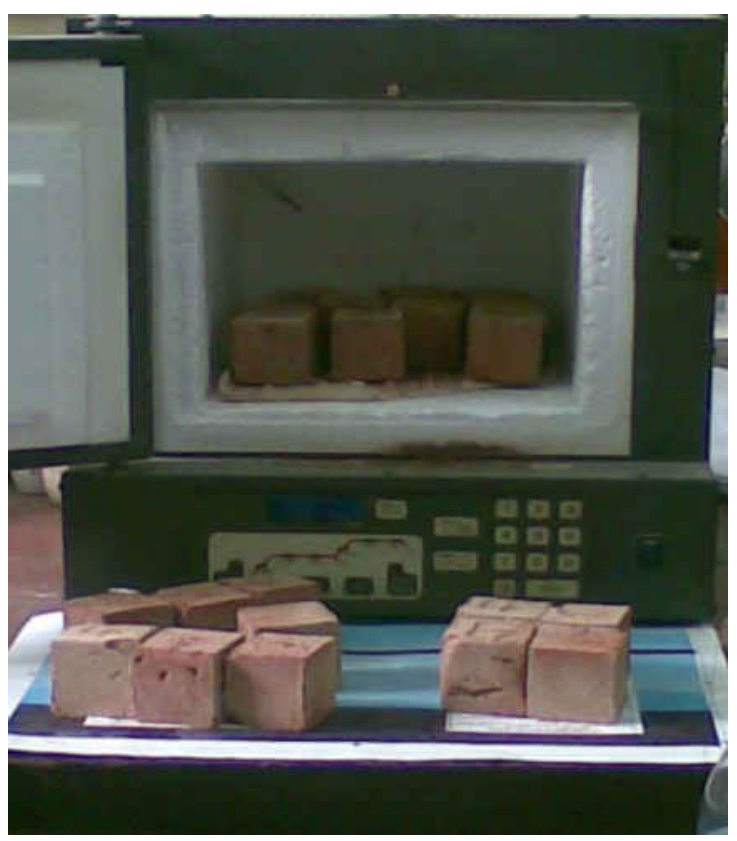

$\mathrm{a}$

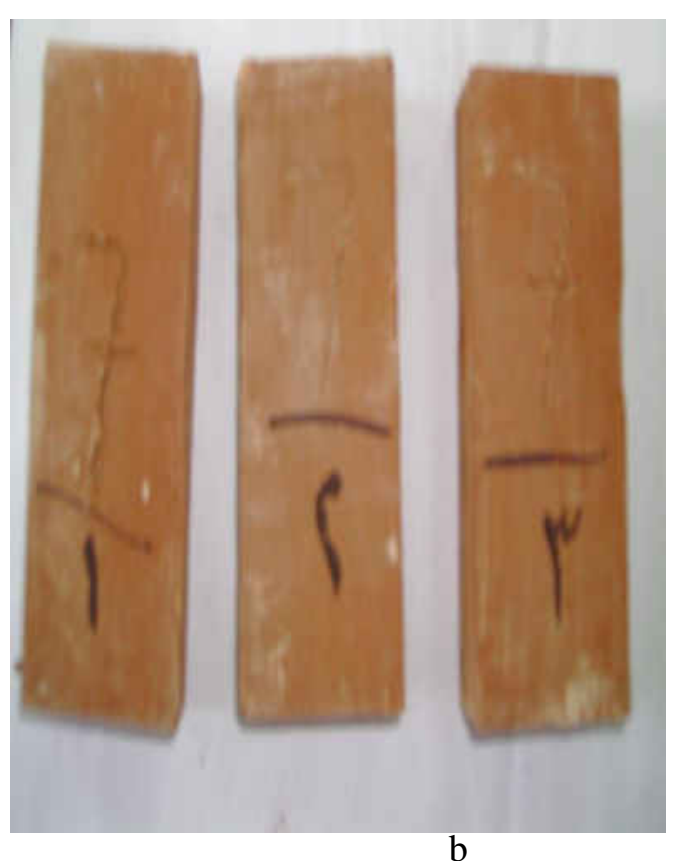

b

Figure 2: Brick samples (a) cubes $5 * 5 * 5 \mathrm{~cm}$. (b) half scale bricks $12.5 * 6 * 3 \mathrm{~cm}$. 


\section{RESULTS AND DISCUSSION}

Various amounts of pre-incinerated WTP sludge, 10\%, 15\%, 20\%, 25\%, 30\% and $50 \%$ on weight basis were mixed with shale to make bricks. The qualities of brick samples were evaluated on their weight loss on ignition, linear firing shrinkage, water absorption, slake durability test, bulk density, and compressive strength.

\section{Water Absorption of Bricks}

Water absorption is a key factor affecting the durability of brick. The less water infiltrates into bricks, the more durability of the brick, and resistance to the natural environment are expected. Thus, the internal structure of the brick must be intensive enough to avoid the intrusion of water. Fig. 3 shows that water absorption for the fact that, bricks increases with increased sludge ash addition. This may be attributed to the addition of ash lowers the plastic nature of the mixture and also decreases the bonding ability of the mixture. When the mixture contains a rather high amount of sludge ash, the adhesiveness of the mixture decreases, but the internal pore size of the brick increases .As result, the quantity of absorbed water increases [5-6, 12, 15-16]. The produced bricks show general compliance with Egyptian standard specifications [1719].

\section{Firing Shrinkage of Bricks}

Shrinkage during firing is unavoidable. Too much volume shrinkage can cause the distortion and breakage of bricks. The quality of brick can be further assured according to the degree of firing shrinkage. As shown in Fig.4, the percentage of shrinkage decreases with increasing sludge ash addition. Because the swellability of the shale is much higher than that of sludge ash, an addition of sludge ash to the mixture should narrow the degree of firing shrinkage. As the amount of sludge ash is increased, the amount of shale used is decreased and hence the amount of organic content also decreased. Thus, this will decrease in firing shrinkage.

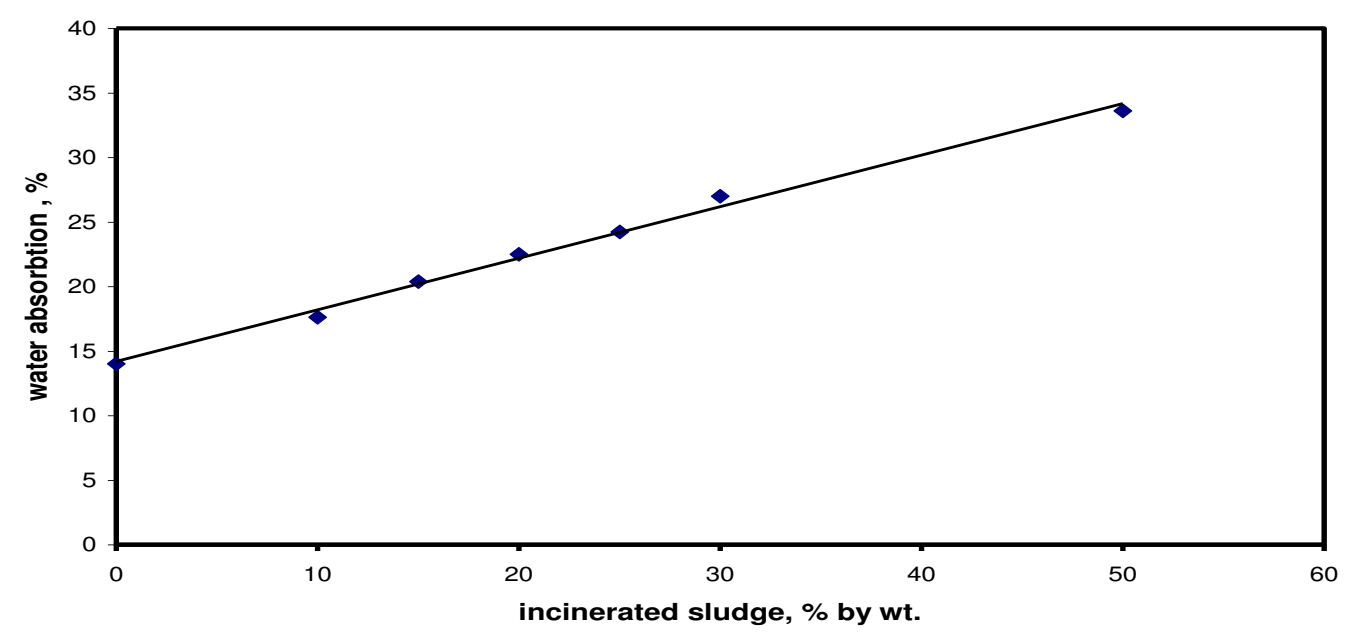

Figure 3: Water absorption of brick samples. 


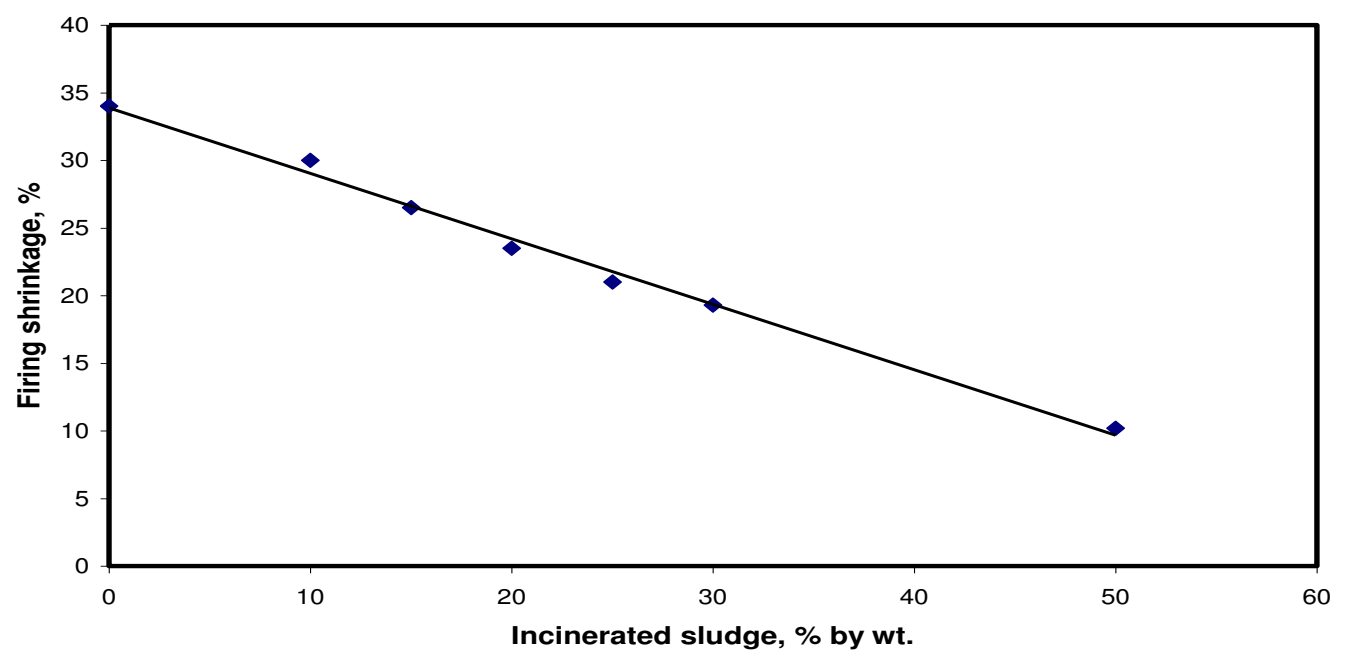

Figure 4: Firing shrinkage of bricks.

\section{Weight Loss on Ignition of Bricks}

The weight loss on ignition of bricks during the firing process is mostly due to the organic compounds and the inorganic $\mathrm{CaCO}_{3}$. Since shale did not receive pretreatment as sludge did, the only source of organic and inorganic matter in the mixture is mainly from shale. As shown from Fig.5, increasing the percent of sludge ash resulted in a decrease in brick weight loss. Also, the results show that without the addition of sludge ash, an uneven surface was found for a normal shale brick. It is speculated that the formation of this unwanted surface was mainly due to the burnt -off organic component during the firing $[12,15]$. The brick weight loss on ignition is not only attributed to the organic matter content in the shale ,but it also depends on the inorganic substances in both shale and sludge ash being burnt off during the firing process . The weight loss on ignition for hand mold clay brick is $15 \%$.

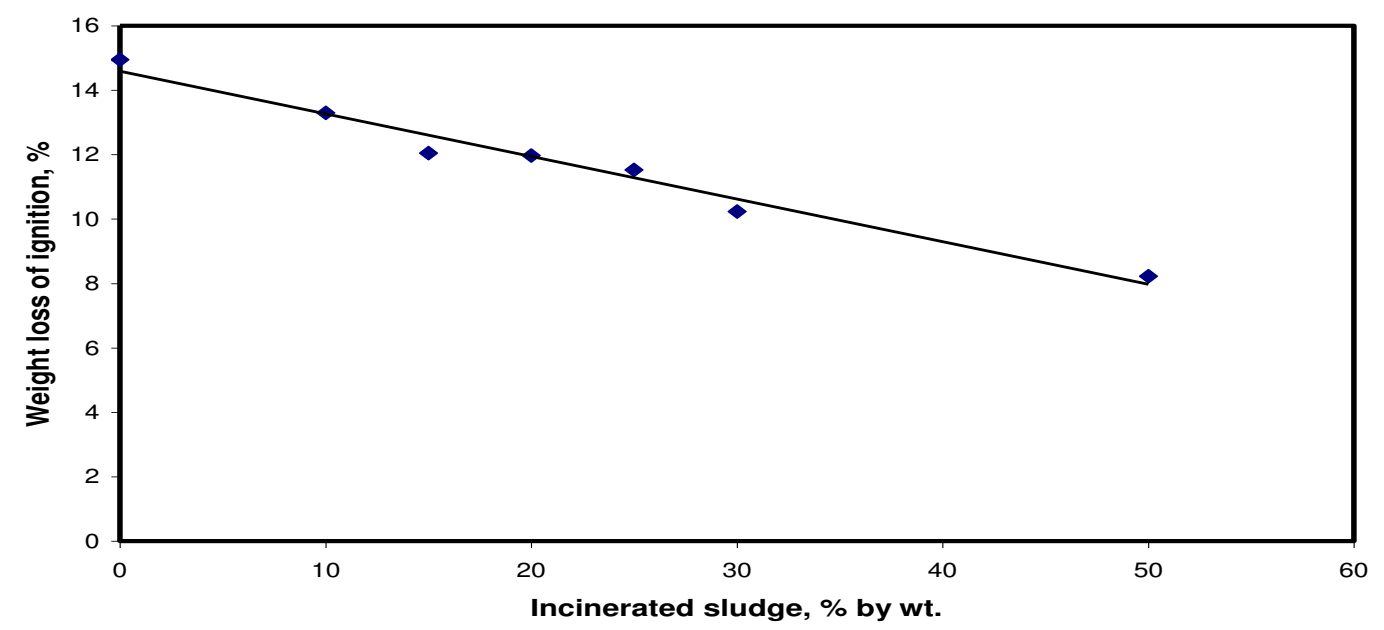

Figure 5 : Weight loss on ignition of bricks. 


\section{Bulk Density of Bricks}

The bricks made with shale or clay normally have a bulk density of 1.8 to $2 \mathrm{~g} / \mathrm{cm}^{3 .}$ The measurements of bulk density of different proportions of sludge ash are demonstrated in Fig. 6. As shown, the bulk density of the bricks is inversely proportional to the quantity of ash added in the mixture. This finding is closely related to the quantity of water absorbed in the brick, as demonstrated in Fig. 3. When the bricks absorb more water, it exhibits a larger pore size than one with less water absorption. As a result, the bulk density becomes smaller [5-6, 12, 15]. The produced bricks match the Egyptian standard specifications $[17,18]$.

\section{Compressive Strength of Bricks}

The compression test is the most important test for assuring the engineering quality of a building material. The results of the compressive strength test on the brick made from both shale and sludge ash mixtures are shown in Fig.7. The results indicate that the strength is greatly dependent on the amount of sludge ash in the brick. This finding is closely related to the quantity of water absorbed as demonstrated in Fig. 3. It decreases with the increase of sludge ash in mixture of brick making. The optimum amount of sludge ash that could be mixed with shale to produce good bonding of bricks was up to $30 \%$ by weight. Additions of up to $20 \mathrm{wt}$. \% sludge ash conformed to minimum compressive strength of $78 \mathrm{kgf} / \mathrm{cm}^{2}$ for use as load bearing bricks for internal walls.

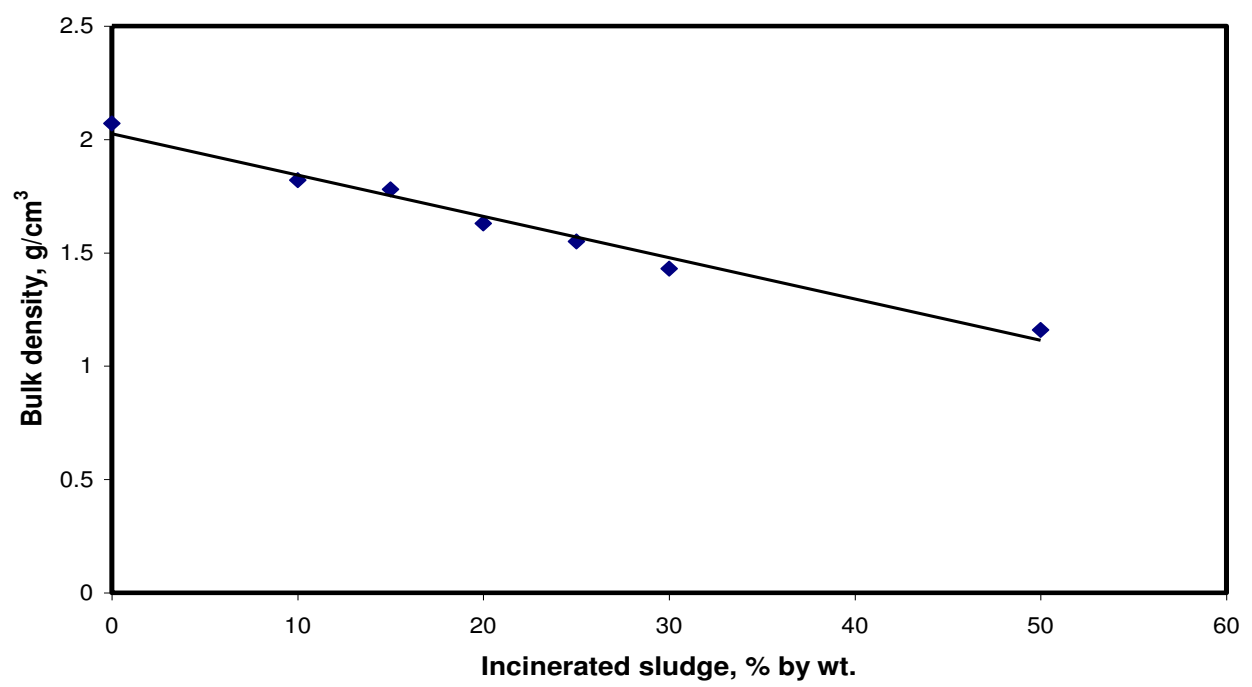

Figure 6: Bulk density of bricks

For non-load bearing partitions with minimum requirement of $20 \mathrm{kgf} / \mathrm{cm}^{2}$, bricks with up to $30 \mathrm{wt} . \%$ sludge ash can be used [16,17]. With 20 to $30 \%$ sludge ash content, the ash-shale bricks show higher compressive strength than normal fired shale bricks (20 to $40 \mathrm{~kg}_{\mathrm{f}} / \mathrm{cm}^{2)}[17-19]$. 


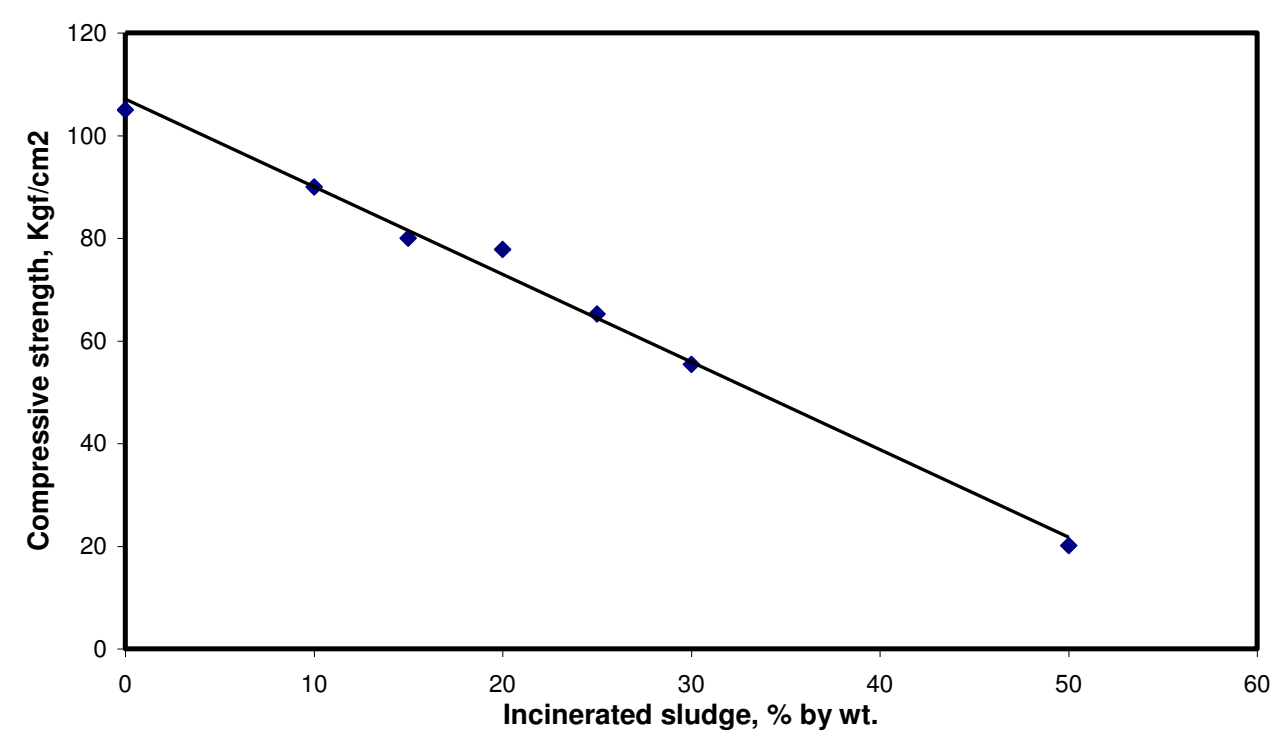

Figure 7 : Compressive strength of produced bricks

\section{6 . Durability Results}

The durability index $\mathrm{Id}_{2}$, is used as an indicator of wind erosion resistance of the brick [20]. The values of $\mathrm{Id}_{2}$ approach zero for samples that are highly susceptible to slaking and approach $100 \%$ for samples that slake very little. The results of index $\mathrm{Id}_{2}$ are shown in Fig.8. It is noticeable that, the produced bricks are more reasonable in building purposes.

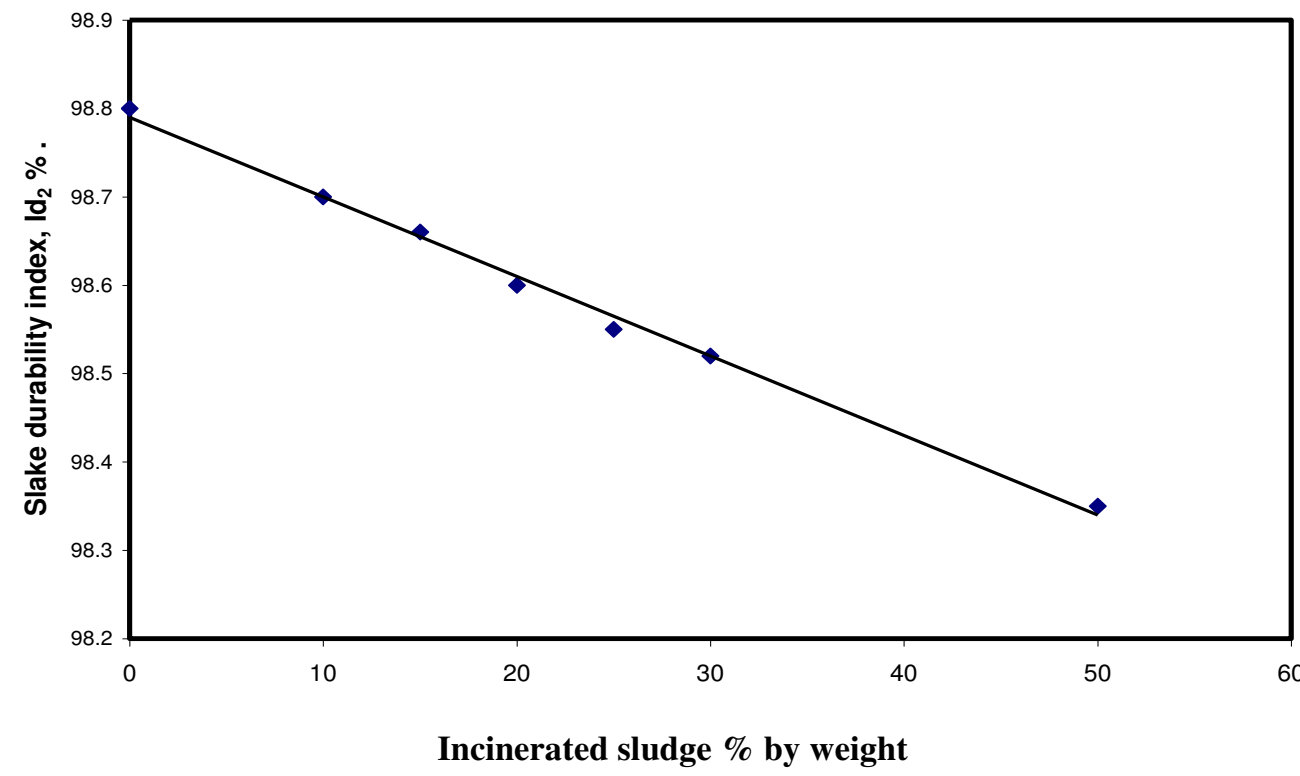

Figure 8 : Slake durability index $\operatorname{Id}_{2}$ of produced bricks 


\section{7 .Efflorescence Results}

The efflorescence of the produced bricks was of Nil class for all the studied mixtures of sludge ash - shale bricks, and match the requirements of Egyptian standard ES : $1756 / 1989$ [17-19].

\section{CONCLUSIONS}

The finding obtained from this study, which was based on the classical hand-molding method of brick making, demonstrated that:

1. Pre-incineration of WTP sludge is necessary before sintering process of bricks, to remove of all organic compounds contained therein. .

2. Increasing the WTP sludge ash content results in a decrease of brick shrinkage, bulk density, weight loss on ignition, and compressive strength of the produced bricks .On the other side brick water absorption increased.

3. The test results indicate that, the brick weight loss on ignition is mainly attributed to the organic matter content in the shale being burnt-off during firing process.

4. With up to $30 \mathrm{wt} \%$ sludge ash added to the shale bricks, the compressive strength measured met the requirements of the Egyptian standard specifications [17-19].

5. The appropriate conditions for manufacturing good quality bricks is $30 \mathrm{wt} \%$ sludge ash with $35 \mathrm{wt} \%$ of moisture content prepared in the molded mixture and fired at $1000{ }^{\circ} \mathrm{C}$.

6. A good correlation between all properties tested was observed.

7. This study showed that WTP sludge ash could be used in brick material.

\section{REFERENCES}

1. Wu, C.-H, Lin, C.-F. and Chen, W.-r. :" Regeneration and reuse of water treatment plant sludge: Adsorbent for cations", J. of Environ. Science and Health, Part A, Vol. A39, No.3, pp.717-728, (2004).

2. Kyncl, M. :" Opportunities for water treatment sludge reuse", GeoScience Eng., Vol. LTV, No.1, pp. 11-22, (2008).

3. Huang, C., Pan, J.R. and Liu, Y. :" Mixing water treatment residuals with excavation waste soil in brick and artificial aggregate making", J. of Environmental Eng., pp.272-277, Feb., (2005).

4. Ramadan, M.o., Fouad, H.A. and Hassanai, A.M. :" Reuse of water treatment plant sludge in brick manufacturing" ,E.R.J.- Shoubra Faculty of Eng., No.8, pp.1-12, Jan., (2008).

5. Huang, C., Pan, J.R., Sun, K.-D. and Liaw, C.-T, :" Reuse of water treatment sludge and dam sediments in brick making ", Water Science and Technology, Vol.44, No.10, pp.273-277, (2001).

6. Rouf, M.A. and Hossain, M.D. :" Effect of using arsenic- iron sludge in brick making ", the Inter. Symposium on fate of arsenic in the environment, Organized by Bangladesh Univ. of Eng. and Technology ( BUET), Dhaka, Bangladesh, pp.193-208, (2008). 
7. Mahzuz, H.M.A., Alam, N.M., Basak, R. and Islam, S.M. :" Use of arsenic contaminated sludge in making ornamental bricks", Int. J. Environ. Science. Tech., Vol.6, No.2, pp.291-298, (2009).

8. Hamer, K. and Karius, V. :" Brick production with dredged harbour sediments: An industrial scale experiments", Waste Management, Vol.22, pp.521-530, (2002).

9. Pan, J.R., Huang, C. and Lin, S. :" Reuse of fresh water sludge in cement making “, Water Science and Technology, Vol.50, No.9, pp.183-188, (2004).

10. Ahmed,A.-M., A, Rizk, A.M, Ibrahim, G.A. and Himida, M.M. :"Utilization of tailings produced from washing plant of Sebaeya phosphate company, Egypt", The $2^{\text {nd }}$ Inter. Conf. for Development and the Environment in the Arab world, Assiut Univ. Center for Environ. Studies, Egypt, March 23-25, pp. 527-536, (2004).

11. Harris, C. :" Constructing Egyptian alternatives: shale brick production in Egypt", 3 pages, (1994), www.Idrc.ca/books/reports/vol.21,No.4/egypt.html.

12. Weng, C.H., Lin, D.-f. and Chiang, P.-C. :" Utilization of sludge as brick mate rials", Advances in Environmental research, Vol.7, pp.679-685, (2003).

13. Egyptian standard of fired clay building units for load Bearing Walls, ES: 1524/993.

14. Rizk,Sh. A.,Mageed,A.A.,Abu-Ali,M.H. : "Dewatering the sludge generated from water treatment plants with two hydro cyclones in series " „J.of Eng. Sciences , Vol.38,No.3,pp.797-806,May (2010).

15. Lin, D.-F. and Weng, C.-H. :" Use of sewage sludge ash as brick material", J.of Environ. Eng., Vol. 127, No.10, pp.922-927, Oct., (2001).

16. Liew, A.-G., Idris, A., Samad, A.-A., Wong, C.H.K., Jaafar, M.s. and Baki, A.M. :" Resuability of sewage sludge in clay bricks", J.Mater cycles waste Management, Vol.6, pp.41-47,(2004).

17. Egyptian Standard of fired clay building units for Nonload Bearing Walls, ES:' 1756/1989.

18. Egyptian standard of Red brucks ES:44-45-46/ December 1965.

19. Gomaa, H.M." Technical tables for concrete and finishing" Engineering consultant and research, Egypt, pp.150-151, (1994).

20. Franklin, J.A. and Dusseault, B.M. :" Rock engineering", M, Graw- Hill publishing company, Tokyo, pp.44-45, (1989). 


\section{استخدام رماد حرق الرويه الناتجه من محطات معالجة مياه الثرب}

\section{في صناعة الطوب}

الهدف الرئيسى لهذا البحث هو دراسة اعادة استخدام الروبه الناتجه من غسيل وحدات ترويق المياه

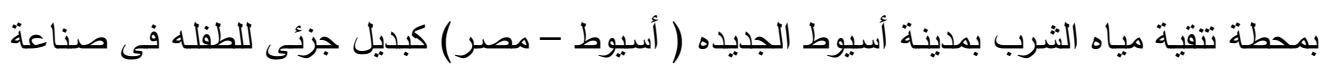
الطوب الطفلى ونظرا لاحتواء هذه الروبـه على نسبه كبيره من المواد العضـويه فانـه يلزم حرقها

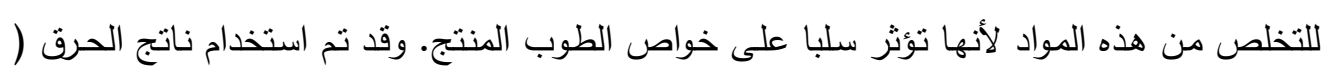

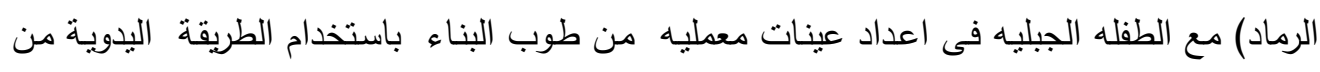
خلال إضافة نسب مختلفة من رماد حرق الروبه تتراوح من 10 \% الى 50 \% الى الى الطفله الجبليه.

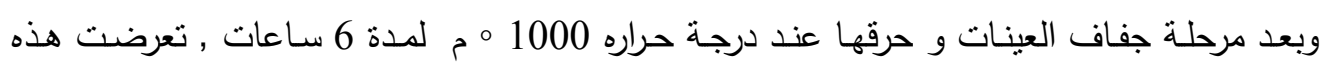

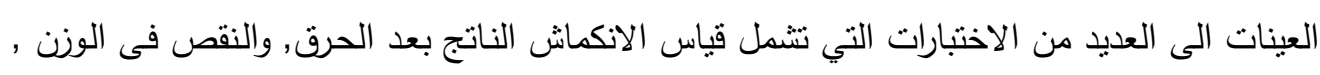

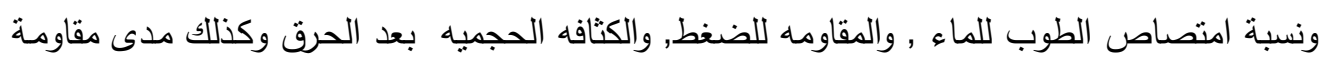

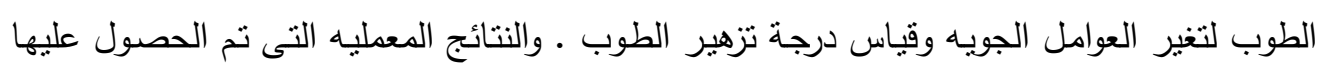

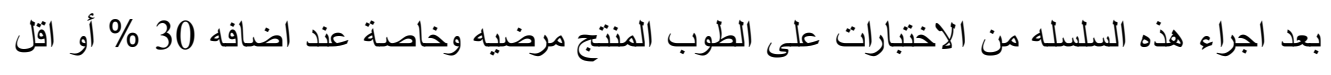

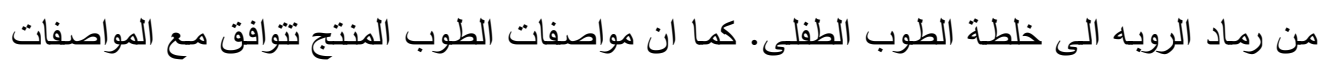

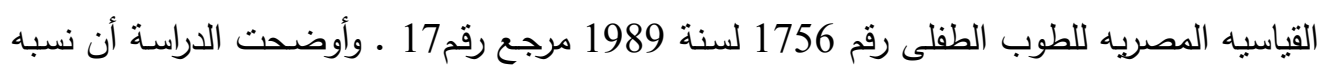

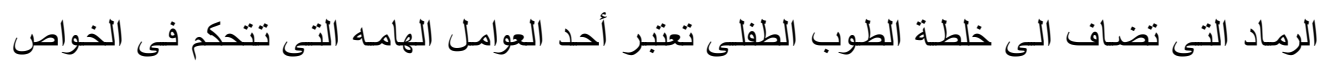

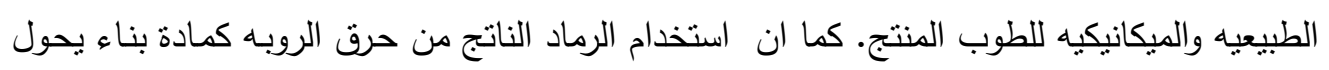

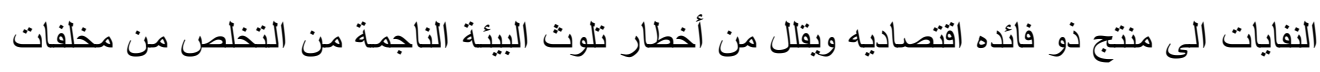
غسيل وحدات ترويق مياه الثرب بطريقه غير سليمة . 